\title{
ANALISIS IMPLEMENTASI UU NOMOR 6 TAHUN 2014 TENTANG DESA DALAM PENGELOLAAN ALOKASI DANA DESA DENGAN METODE LOGIC MODEL (Studi pada Desa Pateken Kecamatan Wonoboyo Kabupaten Temanggung Jawa Tengah Tahun 2016)
}

\author{
Rani Eka Diansari \\ Universitas PGRI Yogyakara, Jl. PGRI No. 117 Sonosewu, Yogyakarta. \\ email: ra_nee.echa@yahoo.co.id
}

\begin{abstract}
Abstrak
Desa adalah susunan pemerintahan terkecil di Negara Kesatuan Republik Indonesia ini. Pengaturan Desa yang baik secara tidak langsung dapat menyebabkan munculnya sistem pemerintahan yang baik pula. Undang-undang no.6 tahun 2014 adalah satu bentuk bahwa pemerintah telah berusaha memperbaiki tata kelola pemerintahan Desa agar dapat berjalan lebih baik. Tata kelola Keuangan pemerintah Desa identik dengan mengelolaan Alokasi dana Desa (ADD). Laporan ADD merupakan sebuah bentuk pertanggung jawaban Desa terhadap pemerintah pusat. Dengan adanya Undangundang No.6 Tahun tahun 2014 tentang Desa, Desa diharapkan mampu mengembangkan potensi Desa dengan optimal. Penelitian ini memfokuskan perhatian pada penerapan prinsip akuntabilitas dalam pengelolaan ADD sebagai implementasi Undang-undang No.6 Tahun 2014 dengan tujuan untuk mendeskripsikan akuntabilitas pengelolaan Alokasi Dana Desa dengan menggunakan Model Logic.

Penelitian ini merupakan rangkaian penelitian yang dilakukan karena sebelumnya dilakukan kegiatan pengabdian masyarakat terkait kesiapan implementasi Undangundang no.6 Tahun 2014 tentang Desa dan ditemukan indikasi bahwa Desa Pateken dalam menyelenggarakan administrasi keuangannya belum sesuai dengan peraturan yang berlaku. Penelitian ini menggunakan metode kualitatif dengan pendekatan studi kasus, alat analisis yang digunakan adalah Model Logika.

Hasil penelitian ini menunjukkan bahwa untuk perencanaan dan pelaksanaan kegiatan Alokasi Dana Desa, sudah menampakkan adanya pengelolaan yang akuntabel dan transparan serta sudah banyak upaya dilakukan untuk mengimplementasikan Undangundang No.6 Tahun 2014, akan tetapi dalam pelaksanaan suatu program Desa belum mengedepankan outcome apalagi sampai dengan impact-nya. Ada beberapa Faktor yang menjadi penghambat pengelolaan program Alokasi Dana Desa adalah terbatasnya kualifikasi aparatur pemerintah Desa, Lemahnya tata kelola keuangan Desa dan keterbatasan pengawasan BPD maupun masyarakat terhadap penyelenggaraan peme-rintah Desa.
\end{abstract}

Kata kunci: Alokasi Dana Desa, Logic Model, Undang-undang No.6 Tahun.

\section{Pendahuluan}

\section{Latar Belakang}

Desa merupakan bentuk pemerintahan terkecil dalam sebuah Negara. Sistem tata kelola Desa yang baik secara tidak langsung menyebabkan tata kelola pemerintahan yang baik. Perubahan paradigma masyarakat yang saat ini semakin memiliki kesadaran terhadap tata kelola pemerintahan membuat kualitas kinerja pemerintah semakin baik dari waktu ke waktu. Hal tersebut ditandai dengan lahirnya undang-undang mengenai 
otonomi daerah Nomor 22 Tahun 1999 dan undang-undang no.25 Tahun 1999 tentang Perimbangan Keuangan Pusat dan Daerah. Kedua undang-undang tersebut menjadi sebuah angin segar dalam mewujudkan semangat demokrasi untuk mewujudkan tujuan Negara dalam mencapai kesejahteraan masyarakat dan menciptakan masyarakat yang adil dan makmur. Undang-undang tersebut diperkuat dengan munculnya undang-undang no.6 tahun 2014 tentang Desa, didalam undang-undang No.6 Tahun 2014 tersebut tata kelola mengenai identitas Desa hingga tata kelola keuangan Desa diatur dan dijabarkan agar mempermudah pemerintah Desa menjalankan aktivitas operasionalnya. Penataan di berbagai bidang berusaha dilakukan untuk menyambut implementasi undang-undang No.6 tahun 2014 tentang Desa tersebut. Penataan dimulai dengan melakukan evaluasi kinerja pada masing-masing Desa. Evaluasi kinerja dimulai dengan pengukuran kinerja Desa. Pengukuran kinerja adalah sebuah komponen dalam sistem akuntabilitas kinerja sektor publik yang bisa digunakan untuk menilai kinerja pengelolaan Desa terutama dalam pengelolaan ADD. Laporan Alokasi Dana Desa yang tersusun dengan baik dapat mencerminkan sebagian tata kelola pemerintahan Desa yang baik. Sesuai dengan tujuan program Alokasi Dana Desa tersebut, maka pengelola alokasi dana Desa harus dilaksanakan dengan baik serta akuntabilitasnya harus dapat dipertanggung jawabkan dalam rangka mengimplementasikan undang-undang No. 6 Tahun 2014 tentang Desa dan mewujudkan program Alokasi Dana Desa untuk kesejahteraan seluruh masyarakat. Dari urgensi latar belakang tersebut peneliti mencoba mengevaluasi akuntabilitas kinerja pengelolaan dana sebagai implementasi undang-undang No. 6 Tahun 2014 dengan menggunakan model logika (Logic Model).

Berdasarkan uraian diatas, penulis tertarik untuk melakukan penelitian dengan judul: “Analisis Implementasi UU Nomor 6 Tahun 2014 tentang Desa dalam Pengelolaan Alokasi Dana Desa dengan Metode Logic Model (Studi pada Desa Pateken Kecamatan
Wonoboyo Kabupaten Temanggung Jawa Tengah Tahun 2016)”.

\section{Rumusan Masalah}

Laporan Alokasi Dana Desa adalah cerminan kondisi tata kelola pemerintahan Desa. Laporan tersebut dapat secara tidak langsung mengindikasikan kondisi keuangan Desa karena laporan tersebut adalah bentuk pertanggung jawaban kinerja pemerintah Desa yang mencerminkan akuntabilitas pengelolaan Alokasi Dana Desa. Dalam pengelolaan ADD sebelum implementasi undang-undang No.6 Tahun 2014 di tingkat Desa di Desa Pateken Kecamatan Wonoboyo Kabupaten Temanggung, terdapat beberapa hal yang mengindikasikan bahwa dalam pengelolaan ADD dan penyusunan Laporan ADD belum sesuai dengan aturan yang di tentukan. Hal tersebut menjadi indikator bahwa sebenarnya Desa tersebut masih menemui kendala dalam menyongsong implementasi Undang-undang No.6 Tahun 2014 tentang Desa.

\section{Tujuan Penelitian}

Tujuan dari penelitian adalah untuk memperoleh gambaran seperti yang telah ditetapkan dalam rumusan masalah, yaitu sebagai berikut:

1. Mendeskripsikan kondisi akuntabilitas kinerja pelaksanaan pengelolaan ADD di Desa Pateken Kecamatan Wonoboyo Kabupaten Temanggung tahun 2016 setelah implementasi undang-undang No.6 tahun 2014 tentang desa.

2. Menganalisis Faktor-faktor apa yang menjadi penghambat pelaksanaan kebijakan Alokasi Dana Desa berdasarkan Permendagri Nomor 37 tahun 2007 tentang Pedoman Pengelolaan Keuangan Desa dan upaya apa yang diambil Pengelola ADD di Desa Pateken Kecamatan Wonoboyo Kabupaten Temanggung Jawa Tengah tahun 2016 setelah implementasi undang-undang No.6 tahun 2014 Tentang Desa.

3. Mengevaluasi indikator kinerja utama 
pada pengelolaan alokasi dana di Desa Pateken Kecamatan Wonoboyo Kabupaten Temanggung sebagai ukuran kesuksesan dalam mencapai kinerja dengan model Logika (Logic Model).

\section{Kajian Pustaka}

\section{Alokasi Dana Desa}

\section{a. Ruang Lingkup Yuridis Alokasi Dana Desa (ADD).}

Dalam Undang-undang Nomor 32 Tahun 2004 mengenai pemahaman tentang eksistensi Alokasi Dana Desa (ADD) tentang Pemerintahan Daerah, dimana secara implisit, dapat dicermati melalui pasal 212 ayat (3) yang mengungkapkan bahwa sumber pendapatan Desa terdiri dari: Pendapatan Asli Desa, Bagi Hasil Pajak Daerah \& Retribusi Daerah Kabupaten/Kota, Bagian dari Dana Perimbangan Keuangan Pusat \& Daerah yang diterima Kabupaten/Kota, bantuan dari Pemerintah yaitu Pemerintah Provinsi dan Pemerintah Kabupaten/Kota serta hibah dan sumbangan dari Pihak ketiga. Dengan memperhatikan substansi yang terkandung dalam susunan ayat (3) tersebut di atas, dapat dimengerti bahwa terdapat hubungan keuangan antara Pemerintah Desa terhadap Pemerintah Kabupaten/Kota dalam 3 (tiga) bentuk yang meliputi:

a. Bagi Hasil Pajak \& Retribusi Daerah Kabupaten/Kota.

b. Bagian dari Dana Perimbangan yang diterima oleh Kabupaten/Kota dari Pemerintah Pusat.

c. Bantuan dari Pemerintah Kabupaten/ Kota.

Surat Edaran Menteri Dalam Negeri Nomor: 140/640/sj Tanggal 22 Maret 2005 perihal Pedoman Alokasi Dana Desa dari Pemerintah Kabupaten/Kota kepada Pemerintah Desa, disamping dituangkan dalam bentuk Surat Edaran Menteri Dalam Negeri Nomor: 903/3172/sj Tanggal 10 Desember 2004 perihal Pedoman Umum Penyusunan Anggaran
Pendapatan dan Belanja Daerah Tahun 2005.

\section{b. Urgensi Pelaksanaan Alokasi Dana Desa}

Menurut Sukesi (2007), Desa membutuhkan perhatian secara proporsional dengan cara memposisikan lembaga Desa dalam batasan hukum yang dapat menjamin keberadaan Desa dengan mempertimbangkan asas keanekaragaman, partisipasi, otonomi asli, demokratisasi serta pemberdayaan masyarakat sebagai satu kesatuan masyarakat hukum yang memiliki batas wilayah yuridis dan berwenang untuk mengatur dan mengurus kepentingan masyarakat setempat berdasarkan asal-usul dan adat istiadat setempat.

\section{Konsep New Public Management}

New Public Management (NPM) adalah sebuah teori manajemen sektor publik yang mempunyai pendapat bahwa praktik manajemen sektor swasta lebih baik dibandingkan dengan praktik manajemen sector publik. Oleh karena itu untuk memperbaiki kinerja sektor publik perlu mengadopsi beberapa praktik dan teknik manajemen yang diterapkan di sektor swasta untuk diimplementasikan dalam sektor publik.

\section{Akuntabilitas Kinerja}

Pasal 7 Undang-Undang Nomor 28 Tahun 1999 menjelaskan bahwa yang dimaksud dengan "Asas Akuntabilitas” adalah asas yang menentukan bahwa setiap kegiatan dan hasil akhir dari kegiatan Penyelenggara Negara harus dapat dipertanggungjawabkan kepada masyarakat atau rakyat sebagai pemegang kedaulatan tertinggi negara sesuai dengan ketentuan peraturan perundang-undangan yang berlaku.

\section{Monitoring dan Evaluasi}

Menurut Peraturan Pemerintah Nomor 39 Tahun 2006, disebutkan bahwa 
monitoring merupakan suatu kegiatan mengamati secara seksama suatu keadaan atau kondisi, termasuk juga perilaku atau kegiatan tertentu, dengan tujuan agar semua data masukan atau informasi yang diperoleh dari hasil pengamatan tersebut dapat menjadi landasan dalam mengambil keputusan tindakan selanjutnya yang diperlukan. Tindakan tersebut diperlukan seandainya hasil pengamatan menunjukkan adanya hal atau kondisi yang tidak sesuai dengan yang direncanakan semula. Sedangkan Evaluasi adalah rangkaian kegiatan membandingkan realisasi masukan (input), keluaran (output), dan hasil (outcome) terhadap rencana dan standar. Evaluasi merupakan kegiatan menilai hasil yang diperoleh selama kegiatan pemantauan berlangsung dan produk yang dihasilkan dari suatu rangkaian program sebagai dasar mengambil keputusan.

\section{Logic Model}

Logic Model adalah sebuah penggambaran visual dari apa program dapat diharapkan untuk menghasilkan dan bagaimana input dapat dikonversi menjadi "hasil" (yaitu, output dan outcome). Logic Model juga disebut hasil rantai, grafik hasil urutan, atau peta strategi. Logic model melihat situasi yang terjadi di dalam sebuah organisasi, kemudian menetapkan hal apa yang dapat diubah untuk sebuah perbaikan dengan menetapkan prioritas utama untuk mengubah situasi tersebut dengan program dan kegiatan yang digunakan untuk mencapai sesuatu yang diinginkan. (Knowlton \& Phillips, 2013) Logic Model berfungsi sebagai alat perencanaan, komunikasi, implementasi, alat pengukuran dan evaluasi.

\section{Metode Penelitian}

\section{Jenis Penelitian}

Penelitian ini menggunakan metode studi kasus pada objek yang akan diteliti dengan pendekatan kualitatif. Menurut Stake (1995) studi kasus adalah strategi penelitian yang mengharuskan peneliti menyelidiki secara cermat suatu program, peristiwa, aktivitas, proses atau sekelompok individu, kasus-kasus tersebut dibatasi oleh waktu dan aktivitas. Peneliti mengumpulkan informasi secara lengkap dengan berbagai prosedur pengumpulan data berdasarkan waktu yang telah ditetapkan.

\section{Teknik Pengumpulan Data}

Dalam rangka mengumpulkan data dan informasi yang valid dan akurat, selain data sekunder berupa laporan ADD, pengumpulan data yang utama (untuk mendapatkan data primer) peneliti akan melakukan wawancara secara mendalam, yang dibantu dengan alat perekam . Untuk memperoleh data dan informasi yang valid dan akurat, dilakukan wawancara secara semi terstuktur, terhadap informan-informan yang dijadikan sumber informasi. Informan yang dipilih telah ditentukan sebelumnya dengan beberapa kriteria yaitu informan yang terlibat langsung mulai dari perencanaan Alokasi Dana Desa hingga pertanggung jawabannya serta memahami dan dapat memberikan informasi (gambaran) tentang pengelolaan Alokasi Dana Desa, yaitu Pemerintah Desa selaku Tim Pelaksana Desa dan Lembaga Pemberdayaan Masyarakat Desa (LPMD) selaku Tim Pelaksana Kegiatan. Sebagai informan dari unsur pemerintah desa, diwakili oleh Kepala Desa, Sekretaris Desa dan Bendahara, sedangkan pihak LPMD diwakili oleh ketua dan anggota yang berkompeten dalam pengelolaan ADD. Selain itu untuk memperoleh data yang berkaitan dengan pengawasan, informan yang dipilih adalah Camat, Sekretaris Kecamatan (Sekcam), Kepala Seksi Pemberdayaan Masyarakat Desa dan unsur Badan Permusyawaratan Desa (BPD).

\section{Teknik Analisis}

Teknik Analisis yang digunakan dalam penelitian ini menggunakan model logika (logic model) yang digunakan sebagai evaluasi akuntabilitas kinerja pengelolaan ADD di Desa Pateken Kecamatan Wonoboyo Kabupaten Temanggung Jawa Tengah. Logic 
Model adalah suatu alat pengukuran kinerja dengan pendekatan model logika untuk menguji kesesuaian antara informasi yang terkait dengan evaluasi Pengelolaan ADD dalam dokumen yang dimiliki oleh Desa Pateken Kecamatan Wonoboyo Kabupaten Temanggung Jawa Tengah sebagai pelaksana Program ADD.

\section{Hasil dan Pembahasan}

Akuntabilitas Kinerja Pelaksanaan Pengelolaan ADD Setelah Implementasi Undang-Undang No.6 Tahun 2014 tentang Desa.

Akuntabilitas kinerja pelaksanaan pengelolaan Alokasi Dana Desa (ADD) adalah merupakan cara dalam mencapai pengelolaan pemerintahan Desa yang baik atau bias disebut dengan Good Government Governance. United Nation Development Program menjelaskan karakteristik Good Governance yang dijabarkan dalam berbagai prinsipprinsip yang menggambarkan sistem akuntabilitas pengelolaan ADD. Prinsip-prinsip tersebut akan dijabarkan lebih lanjut berdasarkan data dan informasi, sejauh mana prinsip prinsip good government governance tersebut dijalankan di wilayah penelitian.

Tingkat akuntabilitas pengelolaan Alokasi Dana Desa setelah munculnya undangundang No.6 Tahun 2014 masih tetap dimulai dari perencanaan, pelaksanaan, dan pertanggungjawaban. Sebagaimana tercantum dalam Peraturan Bupati yang berlaku tentang Pedoman Pelaksanaan Alokasi Dana Desa, yang menjabarkan bahwa secara umum pengelolaan Alokasi Dana Desa di seluruh Desa di wilayah Kabupaten Temanggung harus berpedoman pada prinsip-prinsip sebagai berikut:

1. Pengelolaan tata kelola keuangan Alokasi Dana Desa merupakan bagian yang tidak dapat terpisahkan dari pengelolaan keuangan desa yang tercantum dalam APBDes.

2. Semua kegiatan yang dibiayai oleh dana Alokasi Dana Desa harus direncanakan secara terbuka melalui sebuah forum yang disebut musyawarah perencanaan pembangunan Desa (musrengbandes) yang hasilnya nanti dituangkan dalam Peraturan Desa tentang Anggaran Pendapatan dan Belanja Desa. Kegiatan tersebut nantinya akan dilaksanakan dan dievaluasi secara terbuka dan melibatkan seluruh unsur masyarakat Desa.

3. Semua kegiatan yang dilakukan oleh Desa harus dapat dipertanggungjawabkan baik secara administrasi, secara teknis, maupun secara hukum.

4. Alokasi Dana Desa dilaksanakan sesuai dengan prinsip hemat, terarah, dan terkendali.

5. Alokasi Dana Desa tidak diperkenankan untuk melakukan ganti rugi atas tanah, bangunan-bangunan yang tidak/kurang bermanfaat secara sosial ekonomi, serta tidak diperkenankan untuk melakukan pembangunan tempat ibadah baru.

Dari peraturan yang tercantum diatas dapat dilihat bahwa pelaksanaan pengelolaan Alokasi Dana Desa harus dilaksanakan dengan cara terbuka melalui musyawarah Desa (musrengbandes) serta hasil dari musyawarah dituangkan dalam Peraturan Desa. Dengan adanya sebuah peraturan yang mengatur mengenai pengelolaan dana Desa seperti munculnya undang-undang no.6 Tahun 2014 beserta turunan aturan dibawahnya menunjukkan sebuah komitmen pemerintah dalam rangka mewujudkan terciptanya Good Government Governance. Dengan munculnya Undang-undang No.6 Tahun 2014, Pemerintah Kabupaten Temanggung juga mendukung pemerintah pusat dengan mengatur standart dalam menyajikan pelaporan Alokasi Dana Desa agar mempermudah aparat Desa dalam penyusun laporan Alokasi Dana Desa. Format standart yang dibuat oleh Pemerintah Kabupatan adalah sebuah bentuk keterlibatan pemerintah daerah dalam mensukseskan terlaksananya Alokasi Dana Desa terutama dalam hal pelaporan dan pertanggungjawaban. Selain itu pemerintah juga melakukan pendampingan teknis dilapangan sebagai upaya menumbuhkan tingkat partisipasi masyarakat Desa terutama untuk menggalakkan terciptanya 
pemberdayaan masyarakat Desa guna mengimplementasikan Undang-undang no.6 Tahun 2014. Dalam mengimplementasikan undang-undang no.6 tahun 2014 pada Pengelolaan Alokasi Dana Desa di Desa Pateken Kecamatan Wonoboyo, gambaran keadaan yang diinginkan adalah agar dapat meningkatnya kemampuan aparatur pemerintah Desa agar mampu menyelesaikan setiap tahapan pelaksanaan Alokasi Dana Desa dengan baik sesuai dengan ketentuan yang berlaku sehingga seluruh program yang dirancang oleh pemerintah terkait pembangunan pemerintahan Desa terutama pemberdayaan masyarakat Desa dapat berjalan dengan baik. Adapun Indikator kinerja yang diterapkan dapat dirinci sebagai berikut:

a. Perencanaan Alokasi Dana Desa.

Perencanaan penggunaan dilaksanakan dengan melibatkan seluruh komponen masyarakat desa dalam Musyawarah Desa (Musdes) Alokasi Dana Desa dengan prinsip perencanaan partisipatif pembangunan masyarakat Desa serta pemberdayaan masyarakat Desa sesuai dengan pedoman yang berlaku.

b. Kelembagaan dan pengorganisasian.

Pengorganisasian kelembagaan di tingkat Desa yang terdiri dari Tim Pelaksana dan Tim Teknis agar dapat melaksanakan tugas pokok dan fungsinya masing-masing.

c. Pelaksanaan Kegiatan.

Pelaksanaan kegiatan dalam program Alokasi Dana Desa harus sesuai ketepatan waktu, alokasi dan sesuai dengan yang telah direncanakan dalam musyawarah Desa.

d. Pengawasan.

Monitoring dan evaluasi mentargetkan kinerja pengawasan agar tidak adanya penyimpangan, kekurangan administrasi pengelolaan alokasi dana Desa dan memberikan manfaat alokasi dana Desa yang optimal bagi seluruh lapisan masyarakat di desa tersebut.

\section{Perencanaan ADD}

Perencanaan Alokasi Dana Desa adalah sebuah tahapan awal dalam Program Alokasi Dana Desa. Perencanaan Alokasi Dana Desa bertujuan untuk menyusun kegiatan pelaksanaan Alokasi Dana Desa yang dimulai dari forum Musyawarah Perencanaan Pembangunan Desa (Musrenbangdes), karena sesuai dengan amanat undang-undang No. 6 Tahun 2014 tentang Desa, Musrenbangdes tersebut merupakan sarana pembahasan usulan rencana kegiatan pembangunan di tingkat Desa yang berpedoman pada prinsip-prinsip Perencanaan Pembangunan Partisipasi Masyarakat Desa serta pemberayaan masyarakat Desa. Prinsip tersebut mengharuskan keterlibatan masyarakat dalam proses pengambilan keputusan mengenai apa yang akan dilakukan oleh Desa dalam satu periode kegiatan dan menentukan pembangunan yang akan dilaksanakan terutama yang berlokasi di desa yang bersangkutan serta memastikan bahwa kegiatan yang dilakukan tersebut sudah benar-benar sesuai dengan prinsip pemberdayaan masyarakat Desa. Implementasi undang-undang no. 6 Tahun 2014 tentang Desa dalam pengelolaan program Alokasi Dana Desa di Desa Pateken Kecamatan Wonoboyo Kabupaten Temanggung dilaksanakan dalam rangka pemberdayaan masyarakat serta menekankan proses motivasi berpartisipasi dalam pembangunan Desa untuk menggerakkan perekonomian Desa dan mengurangi pengangguran di Desa. Pelaksanaan prinsip tersebut telah dibuktikan dengan hasil wawancara: “ Perbedaan Alokasi Dana Desa antara sebelum penerapan undang-undang No. 6 Tahun 2014 dan setelah penerapan undang-undang No.6 tahun 2014 sangat jelas, di amanat undang-undang no. 6 tahun 2014 menitik beratkan partisipasi masyarakat Desa pada program pemberdayaan, yang artinya dana Desa adalah untuk pemberdayaan masyarakat sehingga partisipasi masyarakat tetap dihargai dengan nominal tertentu karena program dana Desa tujuannya juga untuk membuka lapangan pekerjaan pada masyarakat Desa, itu inti dari partisipasi dalam pemberdayaan masyarakat oleh sebab itu seluruh lapisan masyarakat selalu antusias kalau membahas Musrenbang karena hal itu 
menyangkut pembangunan Desa ." (Wawancara Kepala Desa Pateken, Kecamatan Wonoboyo, Kabupaten Temanggung Jawa Tengah, pada tanggal, 12 Agustus 2017).

\section{Asas Transparansi}

Melihat transparansi dalam Musyawarah Perencanaan Pembangunan Desa semua hal yang disampaikan oleh seluruh lapisan masyarakat yang berupa kesepakatan dituangkan berita acara yang isinya terkait dengan usulan kegiatan Program Alokasi Dana Desa hal tersebut menunjukkan proses transparansi dalam perencanaan ADD. Hal tersebut juga diperkuat dengan hasil wawancara dengan Kepala Desa, Desa Pateken Kecamatan Wonoboyo sebagai berikut: "Di Pateken sejak awal program Alokasi Dana Desa bahkan sebelum munculnya undang-undang No. 6 Tahun 2014 kita sudah selalu bersama-sama merencanakan pembangunan Desa yang sesuai dengan kebutuhan masyarakat Desa, terkait dengan dana serta bagaimana kegiatan yang ada di desa bisa terlaksana dengan baik dan dapat menguntungkan seluruh anggota masyarakat Desa.” (Wawancara Kepala Desa Pateken Kecamatan Wonoboyo Kabupaten Temanggung Jawa Tengah, tanggal 19 Agustus 2017).

\section{Pelaksanaan Alokasi Dana Desa}

Dalam Pelaksanaan Alokasi Dana Desa, Pemerintah Desa juga masih melibatkan seluruh lapisan masyarakat, karena tujuan dari Alokasi Dana Desa yang diamanatkan undang-undang No. 6 Tahun 2014 tentang Desa adalah pemberdayaan masyarakat jadi seluruh Pelaksanaan kegiatan-kegiatan yang pembiayaaannya bersumber dari ADD sepenuhnya dilaksanakan oleh tim pelaksana Desa, sehingga tujuannya adalah dari Desa untuk kesejahteraan seluruh lapisan masyarakat Desa. Sementara dari sisi pemerintah Desa sendiri agar tercapai keterbukaan dalam proses penyampaian informasi kepada seluruh masyarakat Desa, maka di setiap kegiatan fisik yang telah dilakukan wajib dilengkapi dengan papan informasi kegiatan yang terpasang di lokasi kegiatan tersebut. Papan informasi tersebut hal memuat daftar nama kegiatan, volume kegiatan, besaran anggaran dari Alokasi dana Desa serta kebenaran keterlibatan masyarakat serta waktu pelaksanaan kegiatan sesuai yang telah disepakati dalam proses awal Alokasi Dana Desa yaitu Musrengbangdes. Proses tersebut merupakan bentuk transparansi pemerintah Desa sesuai yang diamanatkan dalam undang-undang no. 6 Tahun 2014 tentang Desa. Transparansi dalam pelaksanaan ADD juga dibuktikan dari hasil wawancara dengan Kepala Desa Pateken Kecamatan Wonoboyo Kabupaten Temanggung sebagai berikut: "Saat ini kondisi Pemerintah Desa lebih baik, karena semua proses yang dilakukan oleh Pemerintah Desa wajib transparan, walaupun sebenarnya untuk Desa yang sumber daya manusianya belum mumpuni terdapat kesulitan akan tetapi kami tetap berusaha memberikan informasi kepada masyarakat Desa, sehingga masyarakat dapat memberikan sumbangsih berupa kritik dan sarannya dalam pelaksanaan program Alokasi Dana Desa." (Wawancara Kepala Desa Pateken Kecamatan Wonoboyo Kabupaten Temanggung Jawa Tengah, tanggal 19 Agustus 2017).

Dari sisi penerapan prinsip akuntabilitas pelaksanaan Alokasi Dana Desa ditempuh melalui sistem pelaporan yaitu laporan bulanan dan laporan masing-masing tahapan kegiatan. Hal tersebut diperkuat dengan wawancara dengan ibu Yeti Anggraeni selaku sekretaris Desa di Desa Pateken Kecamatan Wonoboyo Kabupaten Temanggung Jawa Tengah, sebagai berikut: "Pelaporan sudah dilaksanakan secara berjenjang, sesuai format yang telah ditetapkan dan pelaporan tersebut dilaksanakan secara rutin, setiap bulan dan setiap akhir pelaksanaan tahapan kegiatan, kami juga selalu mempersiapkan pengadministrasian pelaksanaan Alokasi Dana Desa agar memudahkan kami dalam pengajuan anggaran tahap selanjutnya." (Wawancara dengan Sekretaris Desa Desa Pateken Kecamatan Wonoboyo Kabupaten Temanggung, tanggal 26 Agustus 2017).

Hasil wawancara tersebut menunjukkan 
bahwa dalam pelaksanaan ADD dilaporkan perkembangan pelaksanaan kegiatan, dengan demikian dapat diketahui bahwa tanggungjawab pengelola Alokasi Dana Desa tingkat Desa sudah memenuhi ketentuan pembuatan laporan bulanan dan laporan akhir kegiatan dan telah berusaha untuk memenuhi pelaporan terkait format dan ketepatan waktu walaupun hasilnya belum optimal.

\section{Pertanggung Jawaban ADD.}

Dalam Permendagri No.37 Tahun 2007 tentang Pedoman Pengelolaan Keuangan Desa Pasal 19 Bagian Pertama mengamanatkan Tujuan Alokasi Dana Desa yang juga diperkuat dengan munculnya undang-undang No. 6 Tahun 2014 tentang Desa adalah:

a) Menanggulangi kemiskinan dan mengurangi kesenjangan.

b) Meningkatkan perencanaan dan penganggaran pembangunan di tingkat Desa dan pemberdayaan masyarakat.

c) Meningkatkan pembangunan infrastruktur perdesaan.

d) Meningkatkan pengamalan nilai-nilai keagamaan, sosial budaya dalam rangka mewujudkan peningkatan sosial.

e) Meningkatkan ketrentaman dan ketertiban masyarakat.

f) Meningkatkan pelayanan pada masyarakat Desa dalam rangka pengembangan kegiatan sosial dan ekonomi masyarakat.

g) Mendorong peningkatan keswadayaan dan gotong royong masyarakat yang menitik beratkan pada pemberdayaan masyarakat Desa.

h) Meningkatkan pendapatan Desa dan masyarakat Desa melalui Badan Usaha Milik Desa (BUMDes).

Dalam Hal pertanggung jawaban Alokasi Dana Desa di Desa Pateken Kecamatan Wonoboyo Kabupaten Temanggung Jawa Tengah dapat dilihat dalam tabel sebagai berikut:

Tabel 1. Pertanggungjawaban Alokasi Dana Desa di Desa Pateken tahun 2016.

\begin{tabular}{clcc}
\hline No. & \multicolumn{1}{c}{ Keterangan } & Ya & Tidak \\
\hline 1. & Kesesuaian dengan standart laporan. & $\sqrt{ }$ & \\
2. & Ketepatan waktu pelaporan. & & $\sqrt{ }$ \\
3. & Ketepatan Waktu pelaksanaan kegiatan. & & $\sqrt{ }$ \\
\hline
\end{tabular}

Sumber: Wawancara dan Data Alokasi Dana Desa di Desa Pateken, diolah.

Tabel diatas menunjukkan bahwa Pemerintah Desa Pateken Kecamatan Wonoboyo Kabupaten Temanggung telah mengupayakan kesesuaian format sesuai format yang telah ditentukan, akan tetapi terdapat ketidak sesuaian terkait penyabaran format laporan serta waktu dalam penyampaian laporan.

\section{Analisis Faktor-faktor Penghambat Pe- laksanaan Kebijakan Alokasi Dana Desa.}

Beberapa hal yang menjadi penghambat pelaksanaan kebijakan Alokasi Dana Desa berdasarkan Permendagri Nomor 37 tahun 2007 tentang Pedoman Pengelolaan Keu- angan Desa dan upaya apa yang diambil Pengelola ADD di Desa Pateken Kecamatan Wonoboyo Kabupaten Temanggung Jawa Tengah tahun 2016 setelah implementasi undang-undang No. 6 tahun 2014 tentang Desa adalah sebagai berikut:

1. Kemampuan Aparatur Pemerintahan Desa.

Hampir disebagian besar desa mempunyai hambatan terkait dengan spesifikasi dan kemampuan aparatur Desa. Sesuai dengan namanya hakikatnya Desa adalah sebuah wilayah yang masih sebagian besar menganut sistem tradisional bahkan dalam pemelihan perangkat desanya terkadang masih menganut sistem 
dinasti. Kemampuan Aparatur Desa di

Desa Pateken tergolong sangat rendah hal tersebut dibuktikan dengan tabel sebagai berikut:

\section{Tabel 2. Data Aparat Desa di Desa Pateken Kecamatan Wonoboyo Kabupaten Temanggung Jawa Tengah.}

\begin{tabular}{|c|c|c|}
\hline No. & Jenjang Pendidikan & Jumlah \\
\hline 1. & S1 & 0 \\
\hline 2. & D3 & 1 \\
\hline 3. & SMA/SMK & 4 \\
\hline 4. & SMP & 2 \\
\hline 5. & SD & 1 \\
\hline \multicolumn{2}{|c|}{ Total Perangkat Desa } & 8 \\
\hline
\end{tabular}

Sumber: Data Perangkat Desa, Desa Pate-ken 2016.

2. Pengawasan Badan Permusyawaratan Desa yang belum menjalankan fungsinya secara optimal.

Badan Permusyawaratan Desa mempunyai wewenang untuk merancang Peraturan Desa serta melakukan pengawasan terhadap Peraturan Desa dan Peraturan Kepala Desa, akan tetapi pada praktiknya pengawasan Badan Permusyawaratan Desa terhadap penyelenggaraan Pemerintahan Desa tergolong bisa dikatakan lemah. Lemahnya pengawasan badan tersebut disebabkan banyak anggota Badan Permusyawaratan Desa tidak memahami tugas-tugas dibidang pengawasan, karena jenjang pendidikan anggota Badan Permusyawaratan Desa yang masih rendah. Hal tersebut diperkuat dengan wawancara dengan Sekretaris Desa ibu Yeti Anggraeni, sebagai berikut: "Sebagian besar anggota Badan Permusyawaratan Desa rata-rata pendidikannya masih Sekolah Dasar dan SMP, jadi terkait pengawasan hanya berdasar asas kepercayaan saja”.

Terkait dengan lemahnya sumber daya manusia yang ada di desa sebagai pelaksana amanat undang-undang No. 6 tahun 2014 tentang Desa dalam pengelolaan program Alokasi Dana Desa, Kepala Desa Pateken juga menyampaikan beberapa hal sebagai berikut: "Rendahnya pendidikan perangkat Desa serta Badan Permusyawaratan Desa sangat menghambat tercapainya amanat undang- undang No. 6 Tahun 2014 terlebih terkait Tata Kelola Pemerintahan dan Tata Kelola Keuangan Desa dengan baik, maunya kami lari mengimplementasikan segala peraturan pemerintah tetapi tidak berdaya dengan segala keterbatasannya terutama SDM yang mau diajak lari belum siap.” (Wawancara Kepala Desa Pateken Kecamatan Wonoboyo Kabupaten Temanggung), tanggal 26 Agustus 2017).

\section{Evaluasi Indikator Kinerja dengan Model Logika.}

Dengan model logika diperoleh mulai dari proses perencanaan hingga realisasi dan pertanggung jawaban Alokasi Dana Desa dapat ditentukan berdasarkan gambar model logika yang dijabarkan dalam Gambar 1. Model Logika Pengelolaan Alokasi Dana Desa di Desa Pateken Kecamatan Wonoboyo Kabupaten Temanggung memaparkan proses pengelolaan dana desa yang secara logika seharusnya mempunyai hierarki kerangka logis yang berorientasi pada outcomes jangka panjang, akan tetapi kondisi yang terjadi di Desa Pateken saat ini masih jauh dari kerangka Model Logika, saat ini pengelolaan Alokasi Dana Desa di Desa Pateken Kecamatan Wonoboyo Kabupaten Temanggung Jawa Tengah hanya berorientasi pada output saja. Dapat dilihat dalam gambar Logic Model, sebagai berikut: 


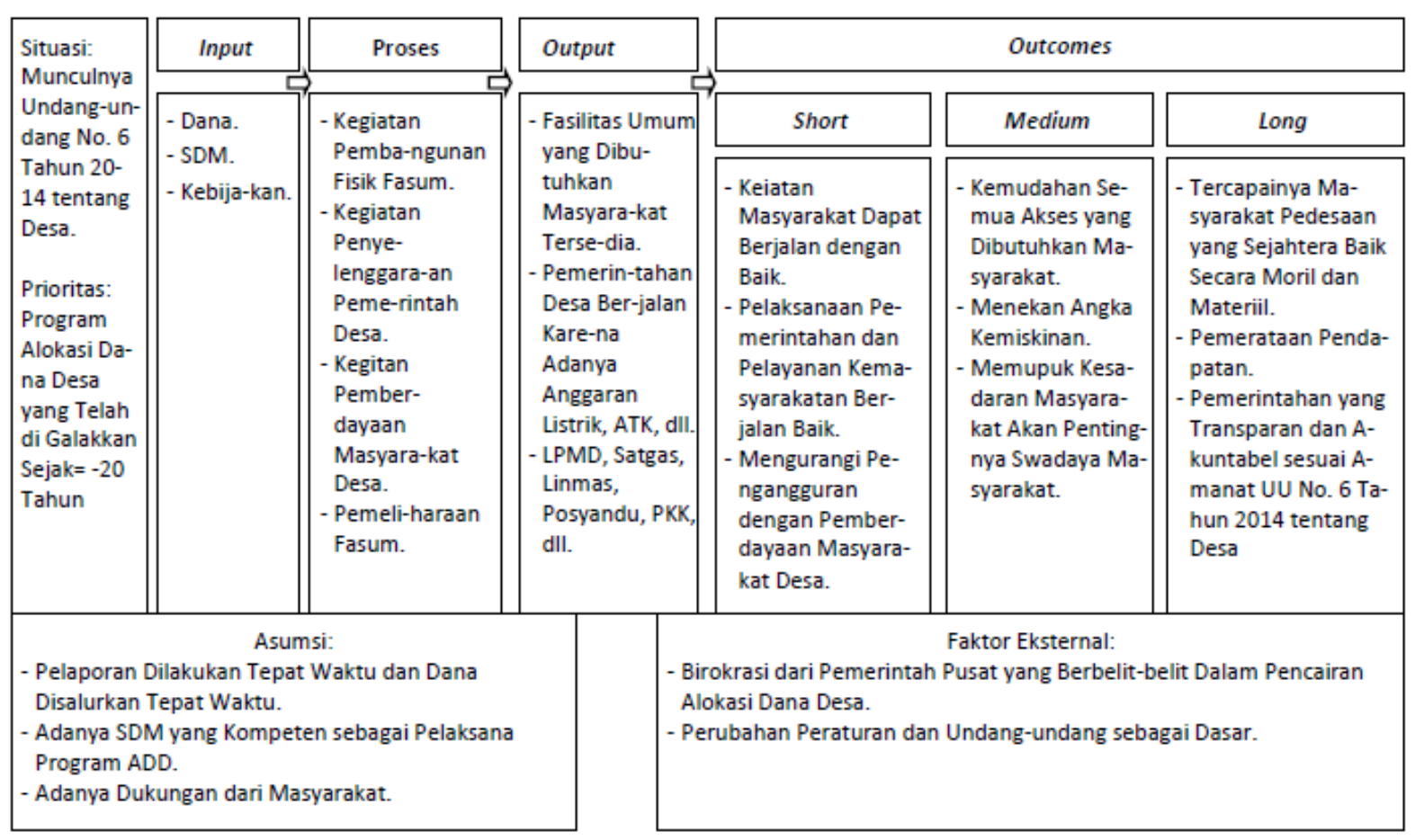

Gambar 1. Logic Model Pengelolaan Dana Desa, Desa Pateken.

\section{Kesimpulan dan Saran}

Implementasi Undang-Undang No. 6 Tahun 2014 Tentang Desa di Desa Pateken Kecamatan Wonoboyo Kabupaten Temanggung dalam pengelolaan Alokasi Dana Desa telah bertahap terlaksana walaupun belum sepenuhnya baik, hal tersebut dikarenakan ada beberapa faktor penghambat diantaranya adalah sebagai berikut:

1. Keterbatasan Sumber Daya Manusia Aparatur Desa di Desa Pateken Kecamatan Wonoboyo Kabupaten Temanggung.

2. Lemahnya Pengawasan Badan Permusyawaratan Desa dalam melakukan pengawasan terhadap aparatur pemerintah Desa.

Sedangkan jika dijabarkan dengan Model Logika, Pengelolaan Alokasi Dana Desa di Desa Pateken Kecamatan Wonoboyo Kabupaten Temanggung masih berfokus pada output saja belum mengedepankan outcome apalagi sampai berorientasi pada impactnya.

Agar Pengelolaan Alokasi Dana Desa dalam terimplementasi dengan baik dan dapat mendorong terciptanya implementasi undang-undang No.6 Tahun 2014 maka disarankan untuk melakukan berbagai macam perbaikan diantaranya adalah:

1. Pendampingan berupa pelatihan terorganisir bagi Perangkat Desa agar dapat meningkatkan kualitas sumber daya manusia.

2. Penyediaan sarana yang memadai untuk tim monitoring Alokasi Dana Desa agar dapat membantu terlaksananya pengelolaan Alokasi Dana Desa dengan baik.

3. Pembinaan terhadapi semua komponen pengelola Alokasi Dana Desa sehingga memberikan pemahaman terkait prinsip partisipatif, transparansi, dan akuntabilitas yang efektif kepada aparatur pemerintah Desa, BPD, lembaga kemasyarakatan desa, semua seluruh tokoh masyarakat Desa.

\section{Daftar Pustaka}

Diansari, Rani Eka, Analisis Kesiapan Implementasi UU No. 6 Tahun 2014 tentang Desa pada Pengelolaan Alokasi Dana Desa. Yogyakarta: Universitas PGRI.

Haryanto, Sahmuddin, dan Arifuddin, 2007. Akuntansi Sektor Publik, Edisi Pertama. Semarang: Universitas Diponegoro. 
Hartono, Eko Budi, 2008. "Pembangunan Partisipatif Masyarakat Desa Implementasinya dalam Program Alokasi Dana Desa”, Tesis S-2 Sekolah Pascasarjana, (tidak dipublikasikan). Purwokerto: Unsoed.

Huberman dan Miles, 1992. Analisis Data Kualitatif, Jakarta: UI Press.

Hudayana, Bambang dan Tim Peneliti FPPD, 2005. "Peluang Pengembangan Partisipasi Masyarakat melalui Kebijakan Alokasi Dana Desa, Pengalaman Enam Kabupaten”, makalah disampaikan pada pertemuan Forum Pengembangan Partisipasi Masyarakat (FPPM) di Lombok Barat 27-29 Januari 2005.

Laporan Alokasi Dana Desa, Desa Pateken, Kecamatan Wonoboyo, Kabupaten Temanggung, Tahun 2016.

Lisa Wyatt Knowlton, Cynthia C Phillips, 2013. The Logic Model Guide Book, copyright 2013.

Manulang, 1991. Dasar-Dasar Manajemen, Jakarta: Ghalia Indonesia.

Mardiasmo, 2002. Otonomi Daerah dan Manajemen Keuangan Daerah, Yogyakarta: Andi.

Moleong, Lexy J., (2002), Metode Penelitian Kualitatif, Bandung: Remaja Rosdakarya.

Peraturan Pemerintah Nomor 72 Tahun 2005 tentang Desa.

Peraturan Pemerintah Nomor 39 Tahun 2006 tentang Tata Cara Pengendalian dan Evaluasi pelaksanaan Rencana Pembangunan.
Peraturan Menteri Dalam Negeri Nomor 37 Tahun 2007 tentang Pedoman Pengelolaan Keuangan Desa.

Rahmawati, Hesti Irna, 2015. “Analisaanalisa Kesiapan Desa dalam Implementasi Penerapan Undang-undang no. 6 Tahun 2014 tentang Desa (Studi pada Delapan Desa di Kabupaten Sleman)”.

Raharjo, Tri dkk., (2011). "Implementasi Kebijakan Alokasi Dana Desa (ADD) Tahun 2011 di Desa Jembul dan Desa Sumengko Kecamatan Jatireji Kabupaten Mojokerto.”

Subroto, Agus, 2009, “Akuntabilitas Pengelolaan Dana Desa (Studi Kasus Pengelolaan Alokasi Dana Desa, Desa-desa dalam Wilayah Kecamatan Tlogomulyo Kabupaten Temanggung 2008”, (Tesis S-2 Sekolah Pascasarjana (tidak dipublikasikan), Semarang: Undip.

Sukesi, 2007. Efektivitas Program Alokasi Dana Desa (ADD) terhadap perekonomian Desa di Kabupaten Pacitan.

Undang-undang Nomor 32 Tahun 2004 tentang Pemerintahan Daerah.

Undang-undang Nomor 33 Tahun 2004 tentang Perimbangan Keuangan antara Pemerintah Pusat dan Pemerintah Daerah.

Undang-undang Nomor 6 Tahun 2014 tentang Desa.

United Nation Development Program, 1997. "Dokumen Prinsip-prinsip Good Governance”, Jakarta: PT.Sinar Abadi.

www.bppk.kemenkeu.go.id. 